\title{
Evaluation of an improved Streptex kit for the grouping of beta-haemolytic streptococci by agglutination
}

\author{
D CASTLE, S KESSOCK-PHILIP, CSF EASMON \\ From the Department of Bacteriology, Wright Fleming Institute, St Mary's Hospital Medical School, London \\ W2 $1 P G$
}

SUMmARY A modified Streptex kit in which the extraction procedure had been simplified was used to group 200 streptococcal strains. Positive reactions could be obtained with live colonies and over $90 \%$ of isolates were correctly grouped from primary isolation plates. Some minor cross-reactions were seen with Streptex, but these were not strong enough to cause any confusion and no isolates were incorrectly grouped. The extraction enzyme in the Streptex kit was relatively poor at extracting the group-specific teichoic acid of group D strains but worked well with groups A, B, C, F and G.

Beta-haemolytic streptococci have traditionally been grouped by precipitation reactions between extracted antigen and group-specific antisera. A number of methods have been used for extracting the group antigens. ${ }^{1-4}$ For the routine laboratory, some of these extraction techniques are timeconsuming and are not ideally suited to the rapid grouping of a small number of isolates as part of daily laboratory routine. In additiion, capillary tube precipitation reactions require the use of relatively large volumes of antiserum. Because of this, increasing attention has been paid to rapid grouping methods based on agglutination. Two systems have been used.

Coagglutination involves the use of two particles. Immunoglobulin $\mathrm{G}$ (IgG) will attach by its Fc fragment to the protein A of the Staphylococcus aureus cell wall leaving the antigen combining Fab fragments free. Staph aureus coated with IgG antisera can be used to agglutinate bacteria carrying the appropriate antigen. ${ }^{56}$ Coagglutination reactions are very economical in terms of antiserum $(0.1 \mathrm{ml}$ serum will coat up to $10 \mathrm{ml}$ Staph aureus suspension) and since they involve two particles, are more sensitive than direct agglutination reactions. Coagglutination forms the basis of the Phadebact streptococ-

Accepted for publication 25 November 1981 cal grouping kit (Pharmacia). As whole organisms are used, no extraction procedure is necessary and colonies can be either identified from the primary isolation plate or from broth subcultures. ${ }^{6}$ Although the principle is simple, there is one major obstacle to the use of standard precipitating antisera in the coagglutination grouping of streptococci. Easmon et $\mathrm{al}^{7}$ showed that there were cross-reactions between streptococci of groups $A$ and $C$ and $B$ and $G$ respectively and that antisera had to be carefully diluted and absorbed accordingly.

An alternative method of streptococcal grouping by agglutination also involves an antibody-coated particle. Here, however, instead of using a whole organism as in coagglutination, an extract of antigen is employed. Immunoglobulin bound to latex particles is used together with an enzyme extract in the Streptex kit (Wellcome Reagents). Easmon et al ${ }^{7}$ used Staph aureus coated with standard commercial precipitating antisera together with extracts prepared by the Streptomyces griseus enzyme extraction method of Maxted. ${ }^{3}$ As antigen extracts were used rather than whole organisms no problems were encountered with cross reactions. These agglutination techniques are marginally less convenient than coagglutination in that they both require extraction of antigen and the separation of the soluble extract.

This paper describes the evaluation of a modified Streptex kit, in which the extraction procedure has been simplified, and a comparison of this method 
with both the formamide extraction/precipitation method $^{2}$ and the Strep griseus extraction/coated staphylococcus agglutination techniques? currently in use in our laboratory.

\section{Material and methods}

\section{BACTERIA}

The beta-haemolytic streptococci used were isolated from a wide variety of clinical specimens sent to the diagnostic laboratory. Reference strains of groups A, B, C, D, F, G obtained from the National Collection of Type Cultures, were used to check the grouping results. A few non-haemolytic group D strains from urinary tract infections were also included. Strains were stored in Robertson's Cooked Meat Broth (Southern Group).

\section{STREPTOCOCCAL GROUPING}

\section{Reference precipitation}

The formamide extraction method of Fuller ${ }^{2}$ was used. Cultures of streptococci in Todd-Hewitt Broth (BBL) were extracted by heating to $160^{\circ} \mathrm{C}$ in formamide and the supernatant used in capillary ring precipitation tests with streptococcal grouping sera (groups A, B, C, D, G and F) (Wellcome Reagents).

\section{Streptex agglutination}

Streptex agglutination was carried out on (a) colonies from primary isolation plates; (b) colonies from purity plates; (c) broth cultures. With the last mentioned, the inoculated broths were tested after $5 \mathrm{~h}$ incubation at $37^{\circ} \mathrm{C}$. If no result was obtained at this time the grouping reaction was repeated after overnight incubation. The extraction enzyme provided in the Streptex kit was reconstituted by the addition of $10 \mathrm{ml}$ sterile distilled water and was stored at $4^{\circ} \mathrm{C}$. With cultures from solid media, colonies were suspended in $0.4 \mathrm{ml}$ extraction enzyme and incubated at $37^{\circ} \mathrm{C}$ for $1 \mathrm{~h}$. With broth cultures one drop of the culture was added to $0.4 \mathrm{ml}$ enzyme and incubation carried out as above. The enzyme extract was used for agglutination reactions without any centrifugation.

One drop of extract was added to one drop of each of the latex particles coated with group-specific immunoglobulin to groups A, B, C, D, F and G, on the clean glass grouping tiles provided. After thorough mixing the tile was rocked gently for a maximum of one minute and the agglutination pattern read. Where agglutination was weak or occurred with more than one latex suspension the test was repeated using the extraction enzyme alone in parallel with the extract. Stock cultures of known streptococcal types were processed periodically to check the specificity of the reagents.
Agglutination of antibody-coated staphylococci

Staphylococcus aureus Cowan I (NCTC 8530) was grown in Brain Heart Infusion broth (Oxoid), killed with $0.5 \%$ formalin, heated at $80^{\circ} \mathrm{C}$ for $5 \mathrm{~min}$ to destroy autolytic enzymes, washed and stored as a $10 \%$ (vol/vol) suspension in phosphate-buffered saline (PBS). Grouping reagents were prepared by adding $0.1 \mathrm{ml}$ of the appropriate streptococcal grouping antiserum (Wellcome Reagents) to $1.0 \mathrm{ml}$ of the staphylococcal suspension, mixing for $15 \mathrm{~min}$ at room temperature, washing twice and resuspending the coated staphylococci to $5 \%$ (vol/vol) in PBS, with $0.01 \%$ sodium azide as preservative. Antisera to groups $\mathrm{A}, \mathrm{B}, \mathrm{C}$ and $\mathrm{G}$, but not groups $\mathrm{D}$ or $\mathrm{F}$, were used.

The extraction enzyme was prepared from Strep griseus by the method of Maxted. ${ }^{3}$ Extraction was carried out under the same conditions as described above for the Streptex technique $\left(37^{\circ} \mathrm{C}\right.$ for $\left.1 \mathrm{~h}\right)$ and the extract used without centrifugation. Agglutination reactions were read at one minute or earlier.

\section{Other identification methods}

Group B streptococci were also characterised by the production of an orange-yellow pigment when cultured anaerobically on Islam's starch serum agar; ${ }^{8}$ group D streptococci by a positive reaction on bile/ aesculin plates.

\section{Results}

The Table shows the distribution of streptococcal groups found during the study, together with the grouping results obtained by precipitation and the two agglutination methods. All strains were betahaemolytic except for seven non-haemolytic group D strains (six isolated from urine) and one group $F$ strain which, although beta-haemolytic on primary culture, became alpha-haemolytic on subculture. Streptex and coated staphylococci correctly grouped $92 \%$ and $90 \%$ of the relevant strains from primary plates respectively, no isolates being incorrectly grouped by either method. A minimum of $10 \mathrm{col}-$ onies $(1 \mathrm{~mm})$ was generally needed to give a positive reaction with the staphylococcal reagents. Streptex was more sensitive, as few as five colonies of a similar size generally being sufficient.

The main deficiency of the Streptex kit was with group D strains, only seven out of 13 being grouped from primary plates. Even when the growth from purity plates was used for extraction, only 10 out of 13 isolates could be grouped. Only extraction from broth cultures was wholly satisfactory. No comparison can be made with the staphylococcal method as no group $D$ reagent was used.

With groups A, B, C and G, Streptex grouping 
Grouping of streptococcal isolates by precipitation and agglutination

\begin{tabular}{|c|c|c|c|c|c|c|}
\hline \multicolumn{2}{|c|}{ Precipitation method } & \multicolumn{3}{|c|}{ Streptex agglutination } & \multicolumn{2}{|c|}{ Staphylococcal agglutination } \\
\hline Group & $\begin{array}{l}\text { No of } \\
\text { isolates }\end{array}$ & $\begin{array}{l}\text { Primary } \\
\text { plate }\end{array}$ & $\begin{array}{l}\text { Purity } \\
\text { plate }\end{array}$ & $\begin{array}{l}\text { Broth } \\
\text { culture }\end{array}$ & $\begin{array}{l}\text { Primary } \\
\text { plate }\end{array}$ & $\begin{array}{l}\text { Broth } \\
\text { culture }\end{array}$ \\
\hline $\begin{array}{l}\text { A } \\
\text { B } \\
\text { C } \\
\text { D } \\
\text { F } \\
\text { G } \\
\text { Non-groupable }\end{array}$ & $\begin{array}{r}75 \\
39 \\
14 \\
13 \\
7 \\
34 \\
18\end{array}$ & $\begin{array}{r}73 \\
38 \\
12 \\
7 \\
7 \\
71 \\
31 \\
32\end{array}$ & $\begin{array}{r}74 \\
38 \\
14 \\
10 \\
7 \\
34 \\
23\end{array}$ & $\begin{array}{l}75 \\
39 \\
14 \\
13 \\
6 \\
34^{*} \\
19\end{array}$ & $\begin{array}{l}71 \\
35 \\
11 \\
\text { ND } \\
\text { ND } \\
30 \\
33 \dagger\end{array}$ & $\begin{array}{l}74 \\
39 \\
13 \\
\text { ND } \\
\text { ND } \\
34^{*} \\
20^{\dagger}\end{array}$ \\
\hline
\end{tabular}

ND = Not done.

*One strain grouped as $\mathrm{G}$ not groupable by reference method.

†Not counting group D and F strains.

from purity plates or from broth, and staphylococcal grouping from broth compared well with results obtained from precipitation grouping. The majority of broth cultures gave satisfactory results after five hours' incubation. One isolate which was not groupable by precipitation gave a group $\mathrm{G}$ reaction when tested from broth culture by both agglutination methods.

Minor cross-reactions were noted with group A, C and $G$ reagents and strains, but these were much weaker than those given by the proper group and presented no problems of interpretation. The Streptex reactions were generally clearer and easier to read than the equivalent staphylococcal reactions. With a heavy pure growth the full one-hour extraction was often not necessary, as little as $15 \mathrm{~min}$ being sufficient to give a satisfactory result. When working from heavily contaminated primary plates Streptex often gave satisfactory results even when a mixed culture had to be sampled in order to obtain sufficient streptococcal colonies.

\section{Discussion}

The modifications to the Streptex kit have improved the extraction process so that it works at $37^{\circ} \mathrm{C}$ and requires no centrifugation to clear the extract before testing. With the exception of group D strains the technique is sufficiently sensitive to give a positive reaction with five colonies. The presence of contaminating organisms does not necessarily prevent accurate grouping from primary plates, where the necessary streptococcal inoculum cannot be obtained without some contamination. Minor cross-reactions do occur, but are not sufficiently strong to cause confusion and no isolates were wrongly grouped.

The main weakness of Streptex is with group D strains. Even with heavy inocula the procedure is relatively poor at extracting the group-specific teichoic acid. This is only likely to present difficulties with haemolytic group D strains isolated from blood, respiratory and genital tracts and purulent material.

We made no direct comparison between Streptex and the Phadebact system (Pharmacia), based on coagglutination, its obvious direct competitor. While coagglutination has the advantage of not requiring antigen extraction, it is often necessary to treat colonies from primary plates with trypsin in order to obtain smooth suspensions. In terms of convenience, trypsinisation can be equated with antigen extraction. Phadebact does not include group $D$ and $F$ reagents.

Although we followed the instructions provided with the Streptex kit in carrying out this evaluation, we have since found that the quantity of reagent used can be scaled down so as to give 200 tests/kit. As the kits are relatively expensive this is an important economy.

We thank Wellcome Reagents for provision of the Streptex kits and the grouping sera used in this study.

\section{References}

' Lancefield RC. A serological differentiation of human and other groups of haemolytic streptococci. J Exp Med 1933;57:57195.

${ }^{2}$ Fuller AT. The formamide method for the extraction of polysaccharides from haemolytic streptococci. Br J Exp Pathol 1938;19:130-9.

${ }^{3}$ Maxted WR. Preparation of streptococcal extracts for Lancefield grouping. Lancet 1948;ii:255-6.

4 Rantz LA, Randall E. Use of autoclaved extracts of haemolytic streptococci for serological grouping. Stanford Med Bull 1955;13:290-1.

${ }^{5}$ Christensen P, Kahlmeter G, Jonsson S, Kronvall G. New method for the serological grouping of streptococci with specific antibodies adsorbed to protein A-containing staphylococci. Infect Immun 1973;7:881-5. 
- Arvilommi H. Grouping of beta-haemolytic streptocci by using coagglutination, precipitation or bacitracin sensitivity. Acta Pathol Microbiol Scand $[B]$ 1976;84:79-84.

' Easmon CSF, Cox Susanne EM, Howard Alison. Grouping of beta-haemolytic streptococci by agglutination. J Clin Pathol 1980;33:386-9.
${ }^{8}$ Islam AKMS. Rapid recognition of group B streptococci. Lancet 1977;i:256-7.

Requests for reprints to: Dr CSF Easmon, Department of Bacteriology, St Mary's Hospital Medical School, London W2 1PG, England. 